\title{
Model Of Social Service In Empowerment Of Social Welfare Issue In Medan
}

\author{
Husni Thamrin, Munzaimah Masril, Walid Musthafa Sembiring \\ Faculty of Social and Political Sciences, University of Sumatera Utara \\ Jl. Dr Sofyan No. 1 Padang Bulan, Medan \\ pungkut@gmail.com
}

\begin{abstract}
Nowadays, Social Welfare Issue Holders (PMKS) in Medan is still exist and keeps growing, in particular such as vagrants and beggars. In fact, more vagrants and beggars that will be found on celebration days such as Ramadhan, Eid al-Fitr, Eid al-Adha, Kong Hu Chu, and many more in Medan. The researchers had done the descriptive research with mixed-methods approach (qualitative and quantitative) at UPTD Pungai Sejahtera, Binjai; Commision of Urban Social Workers (KKSP), a nongovernmental organization in Medan and Study Centre of Child Protection (PKPA), a nongovernmental organization in Medan. The research result states that the cause of an individual/group becomes vagrants and beggars is divided into two factors: internal factor and external factor. The external factors are: 1. Economy, 2. Persuasion by others, 3. Indifference of neighbourhood in case there are people being vagrants or beggars, 4 . Indifference of family in case there are family members being vagrants or beggars. Meanwhile, the internal factors are: 1 . Higher income as a beggar than the one as another profession, 2. Culture of 'losing face' which has worn off, so that the people dare to live homeless and be beggars, 3. Option of being beggars which has been more comfortable to do. Futhermore, the individual or group may return back to live homeless and be beggars due to not enough skill and effort to survive after coming out of Social Institution of UPTD Pungai Sejahtera in Binjai, KKSP and PKPA in Medan, which had given its service to the vagrants and the beggars. On the other hand, the external factors are: 1 . Someone's call or persuasion to work as a beggar and live homeless, 2. High income from being a beggar.
\end{abstract}

Keywords: PMKS, Vagrants, Beggars, Model of Social Service, Empowerment

\section{INTRODUCTION}

The positive and negative effect in development seems hard to be avoided so it always needs effort to develop positive effect and also to decerease and anticipate the negative effect of development. The vagrant and beggar (GEPENG) is one of negative effect of developments especially urban development. The success of urban accelerating development whereas the delay of development in rural area attracts rural-urban migration flow which caused more vagrants and beggars (GEPENG) because of the difficulty in finding settlement and occupation in both urban and rural areas.

Vagrants and beggars has always been a national issue faced in many cities, no exception for developed countries. Vagrants and beggars issue has got a serious attention by central government, local government, or even civil society organization (LSM). Eces and Korf even extremely compare the vagrants as a cancer a city may get because the existence itself can agitate the beauty and comfort of a city, yet it is so difficult and complex to cope with, Rohman Arif,(2010) ${ }^{[1] .}$.

Generally the vagrants are urban people came from rural area and try to have better life in the city, yet they are not supported by enough education level. Specific knowledge competence, and have no fund. As result, the work oddly and not permanently, especially in informal sector like ragpicker, busker, and beggar.

Those who unsucced in pithed fate in the city feel cheap to go back to their hometown, meanwhile they are stranded living in the new place. They live in a slum/squatter are that considered cheap or even free. Vagrants generally have not own any identity card because they are shamefull or scare to be returned to their hometown, meanwhile local government do not 
notice and do not tolerate any resident who has no identity card.

GEPENG is one of social welfare issue holders (PMKS). Social welfare issu holders (PMKS) is a person, family, or society community whom because of an obstacle, difficulty, or disturbance being unable to do his social function, so that his daily needs can not be well fulfilled physically, mentally, and socially. The obstacle, difficulty, and disturbance can be in poverty, state of neglect, disability, social deprivation, backwardness, desolation, and environmental changes, like disaster.

GEPENG is also a part of phenomenon in society which can not be secluded from social life reality. The regulation about the poor and homeless children generally put in The 1945 Constitution of Republic Indonesia (UUD 1945) Article 34 (1) stated that: "The poor and homeless children taken care by the country".

Based on the article, the country has a role in taking care of the poor and homeless children. Furthermore, The 2011 Law no.13 released as the executor of the 1945 Constitution of Republic Indonesia Article 34 (1) to handle the poor in General Law Regulation, the poor by means one who has no livelihood and/or have any livelihood yet unable to fulfill the basic needs well for himself and/or his family. The poor still not have social welfare service so that he needs a social protection.

By the data from North Sumatera Social Welfare Service, there are 4.181 GEPENG in total in north Sumatera. The population of GEPENG in Medan is the second largest, about 1.023 people. Vagrant and Beggar population nationally seem to up and down according to Information and Data Centre (Pusdatin) $)^{[4]}$ of Social Ministry in the last five years 61.090 people in 2007 and rise $17 \%$ to be 194.908 in 2011.

By the data from North Sumatera Social Welfare Service, there are 2.500 beggars in Medan. Meanwhile there are 1.676 vagrants live in Medan. The cause of many beggars and vagrants exist in large city, especially Medan not only because the minimum number of workfield, but also the will factor to try extra hard and the less skill owned, and as a matter of fact we can see many vagrants who are still able to do any job. Try hard by means anything possible to make a living.

As an effort to handle the social welafare issue holders (PMKS) Medan city issued a law to ban the vagrant and beggar in Medan which assigned since 2003, stated in the 2003 Regional regulation No.6) ${ }^{[5]}$ about the ban of vagrant and beggar in Medan. However in fact, Medan has the biggest number of vagrants and beggars among 33 regencies or cities in North Sumatera. The increasing number of GEPENG by years can be seen in the last five years and has becoming a complicated trend Medan city has to face. Supposed the law/regulation have some progress in real implementation to reduce the number of vagrant and beggar.

Medan civil service Police Unit (Satpol PP) as the related parties in the raid of vagrants, beggars, and immoral practice has done their best way to prevent those by doing a routine raid in certain places, yet this have not uttermost done. It can be seen by the existence and the increasing number of vagrants and beggars in Medan, especially in Celebration days such as Eid al-Fitr, Eid al-Adh, Christmas, New Year, Cap Go Meh, etc where those moments be used by the vagrant and beggar to gain profit, because in that moment Indonesian people especially in Medan allocate some money as a part of worship (alms) upon the fortunate they had for the time.

The existence of vagrants and beggars (GEPENG) in cities are also worrisome for the citizen, aside from disturbing people activities in roadway, they also damage the beauty of city. And not least the criminal case did by them, such as pickpocketing, robbery, etc. Therefore, it is important to conduct such research in finding suitable model of social service in empowerment of social welfare issue in Medan.

\section{RESEARCH METHOD}

This research used the combination of qualitative and quantitative approach. The mixedresearch method is a research method which combine or collaborate the quantitative and qualitative method to be used together in a research, to get more comprehensive, valid, reliable, and objective data (Sugiyono, 2012) )[6].

The research conducted by combining the qualitative and quantitative approach about model of social service in empowerment of social welfare issue in Medan. The research is descriptive, because it describes in-depth about a social phenomenon happens based on the reality and facts.

According to Neuman (2005, p.35) ${ }^{[7]}$ " descriptive research present a picture of a specific details of situation, social setting, or relationship" (descriptive research means to give more detail description about social situation, social relationship or social setting). By using this type of 
research it is expected to describe more factual and systematical about factors of someone/group to become GEPENG, factors of someone/group back to become GEPENG after released from NGO or social house, and to describe the suitable model of social service in empowerment of social welfare issue holders in Medan.

The descriptive research means to give more detail description about social situation, social relationship or social setting). By using this type of research it is expected to describe more factual and systematical about factors of someone/group to become GEPENG, factors of someone/group back to become GEPENG after released from NGO or social house, and to describe the suitable model of social service in empowerment of social welfare issue holders in Medan.

The research conducted at UPTD Pungai Binjai social house and Commision of Urban Social Workers (KKSP), an NGO in Medan, and Study centre of Child Protection (PKPA), a NGO in Medan. By focusing in in-house and non-house base social welfare service which give social service to the vagrants and beggars (GEPENG) in Medan.

The data collection technique : First, literature and documentary study from some journals, books, research results and other media related to the research topic, in addition the documentary study also conducted to get secondary information. Second, Research questionnaire which be used to collect information about any program done by social house or non social house in handling the social welfare issue holders (GEPENG), factors of someone/group become a vagrant or beggar, factor of someone/group back to become vagrant or beggar after coming out from rehab centre. Third, in-depth interview to the research informant choosen by purposive sampling. The interview in this research done in-depth and semi-structured to collect information about any program done by social house or non-social house in handling the social welfare issue holders (GEPENG), factors of someone/group becoming a vagrant, factors of someone/group become a vagrant or beggar GEPENG), factor of someone/group back to become vagrant or beggar (GEPENG) after coming out from rehab centre. And Fourth, field observation, an observation based on research topic and the founded reality in field.

The activity of data analysis process in this research started from the data collection by source such as individual in-depth interview, questionnaire, group interview with Participatory Action Research (PAR), observation, and documentation. The collected data are read and studied, sorted all verbal and non-verbal data to be classified based on data category, so that the suitable pattern for the research can be found.

\section{RESULT AND DISCUSSION}

The factors affect someone/group to become vagrant and beggar (GEPENG) in Medan are :

\section{a. Internal Factor}

Internal factor is factor which affects someone/group based on the pressure from himself to choose living as vagrant and becoming a beggar. The internal factor is pressure from the inside self of someone/groupto affect hisself to commit a rule-breaking act, written or not (norm, value, culture, which believed by most people).

Medan has issued a Regional regulation of Medan city No.6 in 2003 about the ban of beggars, vagrants, homeless children and immoral. The regulation is a policy by Medan local government to handle the social welfare issue holders (PMKS) in Medan by doing a regular raid and put those PMKS into UPTD Pungai Sejahtera Binjai to conduct a self-construction and rehab. Whereas the value, norm, regulation which believed by people in society social living consider that living as vagrants and beggars is something inppropriate so it is breaking the rule of community lie, norm, and value.

From the research result known that the internal factors which affect someone/group to become vagrant or beggar in Medan are :

1. The loss of social function to eliminate the self pudency of becoming vagrant and beggar;

2. The comfortable feeling of becoming beggar and live as vagrant;

3. The low education quality and self skill;

The loss of social function that make them "loose face" to live homeless and be a beggar is one of internal factor which caused the vagrant and beggar in Medan. The comfortable feeling being a beggar and live homeless is another internal factor which caused the vagrant and beggar in Medan. The comfortable feeling is a strong stimulus which caused the respondent chose to be beggar and live homelessly. Start by 
the loss of social function one not feel embarrassed to be a beggar and live homeless and it become comfortable for them to do so. According to personality psychology (Sigmund Freud) that the subconscious is the strongest booster which affects someone's act, that means it related to those PMKS GEPENG whom not notice and act unconsciously as they break the written or unwritten rule of norm and value. So that they feel free and comfortable of live homeless and be beggar because they not feel guilty or wrong and think that live homelessly and be beggar is "normal".

The low level of education and self-skill owned is unthinkable by them before deciding to pithed fate in Medan. They did not prepare their education and skill so those whom failed" in pithed fate in Medan "forced to be beggar and vagrant". This has become the internal factor of someone/group who concluded that education and self-skill is the main factor that made them vagrant and beggar. Eventhough the low level of education and skill is not dominant compared to the loss of social function factor, yet this factor undoubtly has become the main excuse for them to be beggar caused by the difficulty of job-seeking for not having a qualified certificate, or not having skill competence needed by work field.

The dominant internal factor of PMKS GEPENG which caused them to live homeless and be beggar dominate by the loss of social function and the comfort of living as vagrant and beggar.

\section{b. External Factor}

The external factor is a factor exist outself of GEPENG which cause someone/ group be vagrant or beggar in Medan, external factor become a strong influence to make someone become vagrant (GEPENG) because of the dominant effect from outside and worsened by internal factor as mentioned above. The external factor able to affect dominantly to anyone, it is based by behavioral phsycology theory by Ivan Pavlop, B.F skiner and others who stated that environment give a strong influence in conducting one's act/behaviour. This research result shows how much the external factor or environment affect someone/group to be vagrant and beggar in Medan.

The research result show that the external factors which affect someone/group to be vagrant and beggar in Medan are :
1. The huge attraction in Medan to cause urban migration and the less number of work field and low income in their hometown;

2. Economic pressure;

3. Persuation from someone else to be beggar;

4. High income from becoming beggar;

5. Indifference of environment (neighborhood) in case there are part of society becoming vagrant and beggar;

6. Indifference of family in case there part of the family becoming vagrant and beggar;

One of the external factor cause someone/group be vagrant and beggar in Medan is the huge attraction in Medan which cause the urban migration and the less number of work field and low income in their hometown. This caused the rural society to do urban migration to pithed fate in Medan. If only they prepare themselve well in education and self-skill needed in work field in Medan it will not be any problem for them, yet it will be a problem when rural society do the migration wthout having enough "skill" to pithed fate such as education, self skill competence needed by workfield in Medan.

Economy pressure is the extention of the failed-factor of rural-urban migration done by rural society which cause a new social problem in Medan that is vagrants and beggars. Economy pressure apparantly afforce them to fulfill their daily needs in Medan, meanwhile it is too shamefull for them to go home. To become a beggar has been a reasonable and promising for them to survive and mostly they get higher income which afforce them to be beggar and live homeless.

Environment factor become af the external factor which cause someone/group become beggar and vagrant in Medan. By the environment means in this research is family, neighbor, spouse, child who are also beggars and vagrants become another factor of someone becoming vagrant and beggar. Based on the research result in field, the previous research reference and theory used as the analysis core in this research, can be concluded that the factorwhich cause someone/group become vagrant and beggar in Medan are :

\section{A. Internal Factors}

1. The loss of social function to eliminate the self pudency to be vagrant and beggar; 
2. The comfort feeling of becoming beggar and live as homeless;

3. The low education level and self-skill owned;

\section{B. External Factors}

1. Huge attraction in the city create urban migration and the low income at hometown.

2. Economic pressure;

3. Persuasion from others;

4. High income of becoming beggar;

5. Indifference of environment (neighborhood) in case there are part of society becoming vagrant and beggar;

6. Indifference of family in case there part of the family becoming vagrant and beggar;

Factor which caused someone/group back again to be beggar after coming out from social house UPTD Pungai Sejahtera Binjai and Commision of Urban Social Workers (KKSP), a non-governmental organization in Medan and Study Centre of Child Protection (PKPA) Medan. Based on research result factors that cause someone/group back again to be beggar and live as homeless are :

A. Internal factor:

1) have no skill, competence, and enough fund to survive after comin out from Social House UPTD Pungai Sejahtera Binjai and NGO KKSP and PKPS Medan which has given social service to vagrants and beggars.

2) the comfort feeling to be beggar than do another work.

B. External factor :

1) persuasion from others to be beggar and live homeless,

2) high income of becoming beggar,

3) the loss of social control in society so the environment become indifference in case there are part of society becoming vagrant and beggar.

Model of social service conducted by inhouse and non-housing system in empowering GEPENG in Medan. Next is the social welfare service model through in-house and non-housing system of empowerment program to return the social function and economic empowerment of PMKS GEPENG in Medan :

\section{Input}

Social welfare service of UPTD Pungai Sejahtera Binjai based on in-house system and work with Operational Procedur Sytem and Mechanism to rehab the PMKS that been raid by civil service Police Unit (Satpol PP) in Medan and other regencies. By doing this, there is an imprint that PMKS are treated as a criminal suspect by civil service police unit (satpol PP) in conducting a PMKS raid in Medan.

Medan has issued The 2003 local regulation no.5 about the ban of vagrant, beggar, homeless, busker, immoral act in Medan street. The regulation meant to be a public policy issued by Medan government to decrease the number of PMKS especially vagrant, beggar, homeless, busker, and immoral women in Medan because those PMKS activities contradicted with society value, policy, rules, and religion norm generally and the existence of PMKS ruin the order of Medan metropolis city face.

The difference of client input process in to the institution seems very different between social welfare service which using in-house system and that which using the non-housing system. PMKS vagrant and beggar (GEPENG) in UPTD Pungai Sejahtera Binjai giving the service with in-house system, has participate level because of the input process forced by the raid of civil service police unit Satpol PP Medan, meanwhile PMKS vagrants and beggars who get social welfare service by LSM/NGO KKSP and PKPA Medan with non-housing system actively participate in the programs because the input process based by own desire to get social welfare service. The fundamental difference in client input process of social welfare service by using in-house and non-housing system.

In Medan itself the social welfare service with non-housing system still limited and difficult to conduct because of some obstacles faced by LSM/NGO such as funds, manpower, facilities, social awareness and support, government, business world, etc. So it is needed to maximize the supporting factors to resolve the obstacle faced by LSM/NGO in Medan which focused in giving social welfare service to PMKS vagrants and beggars (GEPENG). It shows that the social welfare service with in-house system is more effective because it can get funds, facilities, manpower and full attention from government since it is under the Republic Indonesia Ministry of Social Issue. So that the social welfare service with in-house system can be more effective and 
efficient and can return the social function and develop the economy of PMKS vagrants and beggars.

\section{Social welfare service through empowerment in-house and non-housing system.}

Based on research result, known that the empowerment programs done to return the social function and economy of PMKS GEPENG by UPTD Pungai Sejahtera Binjai or LSM/NGO KKSP and PKPA in Medan has some differences. The difference become contrary when we take look at the empowerment conduct by UPTD Pungai Sejahtera Binjai by giving house facility, free meals for the family memners of PMKS for two years maximum, meanwhile NGO KKSP use a shelter for PMKS GEPENG and others to live momentarily whilst make living.

Next for the empowerment program such as skill, competence given to PMKS GEPENG also different, in empowerment program conduct by inhouse system the PMKS GEPENG participate in some programs such as mechanic workshop, screen printing, saloon in adjusted to the fund, without being asked whether they are willing or not to do the program. While the non-housing system conduct based on the interest of PMKS for example the interest of PMKS GEPENG is in workshop area, screen printing, saloon, etc yet because of the lack of fund, facility, medium, and manpower not all of the wishes can be fulfilled.

Supposed the service given can develop PMKS GEPENG participation, so that the empowerment program can run well and PMKS GEPENG who join the program can get the skill which be useful to make money after coming out from social house and LSM/NGO. So there will be no need for them to be back again live homelessly and be beggars. This still necessary to effectively developed more about the social welfare service to return the social function and economy development of PMKS GEPENG.

The empowerment programs conduct by UPTD Pungai Sejahtera or LSM/NGO KKSP and PKPA still not effective in returning the social function and PMKS GEPENG empowerment. This can be seen from the previous research result which stated PMKS will be back again to the street and be beggars because they still unable to fulfill the living needs by work using the skill they got from UPTD Pungai Sejahtera Binjai or LSM/NGO KKSP and PKPA, so that they go back to be beggar again.
Based on that matter it can be concluded that the empowerment programs conducted by UPTD Pungai Sejahtera or LSM/NGO KKSP and PKPA still can not fully return the social function and economy development of PMKS GEPENG. For example the automotive/workshop skill which given at UPTD Pungai Sejahtera or LSM/NGO KKSP to PMKS GEPENG, after getting the training and skill development the PMKS GEPENG still unable to use their skill because the lack of fund to open a workshop or not accepted to work at any workshop.

\section{The utilization of Society Based Social Welfare Mode (WKSBM) as social control}

Social control by Society Based Social Welfare Mode (WKSBM) could be seen by the active role of society such as youth organization, young muslim activist, board of Mosque affluence, etc support the service in case part of their society become PMKS, so that they could help in giving social service such as fund, shelter, cooking class, baking class which can be useful to start enterpreneurship. By active role of society as social control can build up self pudency toward society in case there are part of society become beggar or vagrant so that social control acted as "fortress" from those who act contrary with applicable value, norm, policy in society. However the society based WKBSM control should not be abused to judge the resident or society member who become PMKS but meant as a receptacle to give social service through local wisdom by prioritizing applicable society norm and policy.

\section{The participation of business world, industry and trade service by using the ability or handicrafts produced by PMKS GEPENG}

This closely related to the holistic (whole) social welfare service conducted by UPTD Pungai Sejahtera aimed to make the empowerment PMKS GEPENG be sustainable (sustainability program) through in-house system or LSM/NGO KKSP and PKPA Medan through non-housing system.

The distribution of PMKS GEPENG who has got skill from UPTD Pungai Sejahtera or LSM/NGO KKSP and PKPA Medan is a unity series to optimize the empowerment program, for that there are knowledge, information, link needed from UPTD Pungai Sejahtera or LSM/NGO KKSP and PKPA Medan to distribute the skillful manpower who can work in bussiness world 
suited with their skill, competence. Some empowerment programs conducted by LSM/NGO KKSP and PKPA Medan are giving handicraft training for the parents of homeless children, or PMKS GEPENG so that they will have their own bussiness. The obstacle faced is not having available market which can accommodate the product, so that the bussiness world, industry and trade service of Medan should participate to facilitate the products from LSM/NGO KKSP and PKPA members.

\section{Monitoring and Evaluating}

Monitoring and evaluating after PMKS especially vagrants, beggars, buskers, immoral women, coming out from UPTD Pungai Sejahtera Binjai and LSM/NGO KKSP and PKPA Medan has never been done. Monitoring and evaluating through companion is really needed to control the program sustainability the return of social function and economy development that has been done or received by PMKS clients in government services or LSM/NGO. Thus caused the PMKS especially vagrants, beggars, buskers, homeless children, immoral women, who has come out be back again to the street because of those internal and external factors discussed on the previous chapter.

Monitoring and evaluating become an inseparable part in giving social welfare service which conducted by in-house or non-housing system. Because from monitoring and evaluating can be found out whether the PMKS especially vagrants, beggars, buskers, homeless children, immoral women who has got the empowerment program conducted by UPTD Pungai Sejahtera Binjai or LSM/NGO KKSP and PKPA Medan has finally got their social function back and be able economically, so that they will never go back to make living on the street.

\section{CONCLUSION}

Based on the research result and discussion, also to answer the questions in this research the conclusion are :

1. The factors affect someone/group to become vagrant and beggar (GEPENG) in Medan are internal and external.

a. Internal Factors :
$>$ The loss of social function to eliminate the self pudency to become vagrants and beggars;

$>$ The comfort feeling to become beggars and live as homeless;

$>$ Low education level and skill owned.

b. External Factors :

$>$ Huge attraction in the city create urban migration and the low income at hometown.

$>$ Economic pressure;

$>$ Persuasion from others;

$>$ High income of becoming beggar;

$>$ Indifference of environment (neighborhood) in case there are part of society becoming vagrant and beggar;

$>$ Indifference of family in case there part of the family becoming vagrant and beggar.

2. Factor which caused someone/group back again to be beggar after coming out from social house divided into internal and external factors :

a. Internal Factors are :

$>$ have no skill, competence, and enough fund to survive after comin out from Social House UPTD Pungai Sejahtera Binjai and NGO KKSP and PKPS Medan which has given social service to vagrants and beggars.

$>$ the comfort feeling to be beggar than do another work.

b. External Factors are :

$>$ persuasion from others to be beggar and live homeless

$>$ high income of becoming beggar

$>$ the loss of social control in society so the environment become indifference in case there are part of society becoming vagrant and beggar.

3. Model of social welfare service conducted by inhouse and non-housing system in Medan :

a. to issue a policy of local regulation to give sanction and fines for those who give money directly to beggars on the street and also to give sanction/fines to person/group who organize others to work as beggars in Medan;

b. to activate the utilization of Society Based Social Welfare Mode (WKSBM) as social control by conducting local wisdom in Medan;

c. to persuade participation of business world, industry and trade service by using the ability or 
handicrafts produced by PMKS GEPENG who comes out from UPTD Pungai Sejahtera Binjai or LSM/NGO which focus on giving social welfare service through empowerment programs;

d. to monitor and evaluate through companion to PMKS GEPENG who came out from UPTD Pungai Sejahtera Binjai or LSm/NGO Medan so that they will not go back again to the street.

\section{SUGGESTION}

Suggestions given in this research as an effort to give social welfare service to social welfare issue holders in Medan are:

a. To the stakeholder of Medan government

$>$ To issue a policy of local regulation to give sanction and fines for those who give money directly to beggars on the street and also to give sanction/fines to person/group who organize others to work as beggars in Medan

$>$ To give sanction/fines to person/group who organize others to work as beggars in

$>$ To Civil service police unit in Medan to promote humanity principles and do not any harm in conducting PMKS raid and not to treat PMKS as criminal suspect.

$>$ To have an MoU with UPTD Pungai Sejahtera Binjai, LSM/NGO which focus on giving social welfare service to distribute the skilfull manpower and handcrafted products of PMKS GEPENG to bussiness world through Industry and Trade Service of Medan or any related services.

$>$ To activate The utilization of Society Based Social Welfare Mode (WKSBM) as social control which promote local wisdom of Medan society.

b. To UPTD Pungai Sejahtera Kota Binjai:

$>$ Input process of PMKS into UPTD Pungai Sejahtera Binkai is not only from the Sat-Pol PP raid result but it should be open to all PMKS who deserve to have social service;

$>$ In client-handling, starts from assesment program, planning, intervention, evaluation, and termination supposedly promote the interest of PMKS GEPENG itself so that participation of PMKS GEPENG can be maximum in joining the program;

$>$ Social welfare service through monotonic in-house program make PMKS bored, so it needed to consider another way in giving empowerment program to PMKS GEPENG;

$>$ Monitoring and evaluating to PMKS GEPENG who has been out or has had social service from UPTD Pungai Sejahtera Binjai is must needed to make sure that PMKS GEPENG will not going back to the street living as homeless and beggar.

c. To LSM/NGO KKSP and PKPA Medan:

$>$ In giving social service welfare through empowerment program to PMKS GEPENG by handiness program, skills needed in work field.

$>$ Maximize the role of social worker as broker (agent) in distribute the PMKS GEPENG whom has got the handines, skill during the study in NGO/LSM KKSP and PKPA to the bussiness world, also distribute the handicraft products made by the conducted society PMKS GEPENG in LSM/NGO KKSP and PKPA.

$>$ Monitoring and evaluating the PMKS GEPENG who has been outor has got social service from LSM/NGO KKSP and PKPA is a must needed to check whether the PMKS GEPENG will be back to the street living as homeless and beggar.

\section{ACKNOWLEDGEMENT}

Writers send their gratitude to Social Science Department, Social and Political Science Faculty of University of North Sumatera. And also their greatest gratitude to University of North Sumatera Research Centre and Ministry of Research, Technology and Higher Education for giving them financial support to the research.

\section{REFERENCES}

Neuman, W Lawrence. (2006). Social Research Methode: Qualitative and Quantitative Approach (Sixth Editio). Needham Heights. MA: Allyn \& Bacon.

Peraturan Daerah Nomor 6 tahun 2003 tentang larangan Gelandangan dan Pengemis di Kota Medan.

Pusat data dan Informasi (Pusdatin) tahun 2012

Rohman Arif, (2010). "Program Penanganan Gelandangan, Pengemis, Anak Jalanan Terpadu Melalui Penguatan Ketahanan 
Ekonomi Keluarga Berorientasi Desa" Disampaikan Pada Acara Workshop Penanganan Gelandangan di Perkotaan. Jakarta: Kementerian Sosial R.I.

Republik Indonesia. 2011. Undang - undang Nomor 13 tahun 2011 tentang Penanganan Fakir miskin. Jakarta : Sekretariat Negara
Sugiono.,2009, Metode Penelitian Kuatitatif, Kualitatif dan R\&D, Vol 1,Bandung: CV. Alfabeta

Undang - Undang Dasar Tahun 1945 